\title{
The action of ten secreted aspartic proteases of pathogenic yeast Candida albicans on major human salivary antimicrobial peptide, histatin 5*
}

\author{
Oliwia Bochenska1, Maria Rapala-Kozik², Natalia Wolak', Wataru Aoki³, Mitsuyoshi Ueda³ and \\ Andrzej Kozik ${ }^{\circledR}$
}

1Department of Analytical Biochemistry, Faculty of Biochemistry, Biophysics and Biotechnology, Jagiellonian University in Krakow, Kraków, Poland; '2Department of Comparative Biochemistry and Bioanalytics, Faculty of Biochemistry, Biophysics and Biotechnology, Jagiellonian University in Krakow, Kraków, Poland; 'Division of Applied Life Sciences, Graduate School of Agriculture, Kyoto University, Kyoto, Japan

\begin{abstract}
Candida albicans, belonging to the most common fungal pathogens of humans, exploits many virulence factors to infect the host, of which the most important is a family of ten secreted aspartic proteases (Saps) that cleave numerous peptides and proteins, often deregulating the host's biochemical homeostasis. It was recently shown that C. albicans cells can inactivate histatin5 (His5), a salivary histidine-rich anticandidal peptide, through the hydrolytic action of Saps. However, the current data on this subject are incomplete as only four out of ten Saps have been studied with respect to hydrolytic processing of His5 (Sap2, Sap5, Sap9-10). The aim of the study was to investigate the action of all Saps on His5 and to characterize this process in terms of peptide chemistry. It was shown that His5 was degraded by seven out of ten Saps (Sap1-4, Sap7-9) over a broad range of $\mathrm{pH}$. The cleavage rate decreased in an order of Sap2 $>$ Sap9>Sap3 $>$ Sap7 $>$ Sap4>Sap1>Sap8. The degradation profiles for Sap2 and Sap9 were similar to those previously reported; however, in contrast to the previous study, Sap10 was shown to be unable to cleave His5. On a long-time scale, the peptide was completely degraded and lost its antimicrobial potential but after a short period of Sap treatment several shorter peptides (His1-13, His1-17, His1-21) that still decreased fungal survival were released. The results, presented hereby, provide extended characteristics of the action of C. albicans extracellular proteases on His5. Our study contribute to deepening the knowledge on the interactions between fungal pathogens and the human host.
\end{abstract}

Key words: secreted aspartic proteases, Sap, Candida albicans, antimicrobial peptides, histatin 5 , candidiasis

Received: 21 March, 2016; revised: 10 May, 2016; accepted: 13 May, 2016; available on-line: 08 July, 2016

\section{INTRODUCTION}

The saliva plays a key role in the maintenance of a stable oral microflora, being a source of (glyco)proteins and peptides potentially serving as a growth substrate for microorganisms but also containing a wide variety of defensive systems that protect oral tissues against excessive microbial colonization (van't Hof et al., 2014; Valentijn-Benz et al., 2015). Ones of the the most abundant salivary components that possess potent antimicrobial activities are histatins, a family of low-molecular-weight, histidine-rich, cationic peptides produced and secreted by human parotid and submandibular-sublingual glands (Helmerhorst et al., 2006). The family of histatins contains 12 members of which histatin 5 (His5), composed of 24 amino acid residues is one of the most prominent and the most potent with regard to antifungal activity, especially against Candida albicans, one of the most common fungal pathogen in humans. His 5 is taken up by C. albicans cells through binding to cell wall proteins (Ssa1/2) and glycans. Once internalized, His5 inhibits the mitochondrial respiration and induces the formation of reactive oxygen species, causing the ultimate cell death by volume dysregulation and ion imbalance triggered by osmotic stress (Puri \& Edgerton, 2014). Recent studies indicated that besides the antifungal activity His5 is able to reduce adhesion of $C$. albicans to epithelial cells (Moffa et al., 2015).

C. albicans colonizes mucosal surfaces, including the oral cavity wherein it constitutes $40-60 \%$ of all yeast species present (Samaranayake et al., 2009; Dynowska et al., 2014). In healthy individuals this fungus is usually a harmless commensal. However, when the natural microflora of the oral cavity is imbalanced, owing to the reduced immunity, long-term use of antibiotics and drugs such as inhaled steroids, the use of dentures, immunosuppressive conditions such as in HIV patients, malignancies such as leukemia and nutritional deficiencies or age, the individual becomes at increased risk of infectious diseases such as candidiasis or thrush (Singh et al., 2014). To remain a stable commensal organism or, in opposite, to become a causative agent of a serious disease, C. albicans defends itself against a multiplicity of innate immune mechanisms by activation of fungal virulence traits, among which the production of secreted aspartic proteases (Saps) plays a major role (Hube, 2001; Naglik et al., 2004; Schaller et al., 2005). Ten distinct Saps, similar in structure and function, of which eight (Sap1-8) are released into the extracellular space while Sap9 and Sap10 are glycosylphosphatidylinositol (GPI)-anchored to the cell membrane/wall, display a broad substrate specificity

e-mail: andrzej.kozik@uj.edu.pl

*These data were presented at the $43^{\text {rd }}$ Winter School of Faculty of Biochemistry, Biophysics and Biotechnology, 16-20 February, 2016, Zakopane, Poland.

Abbreviations: AMP, antimicrobial peptide; CFU, colony-forming units; ESI, electrospray ionization; GPI, glycosylphosphatidylinositol; His5, histatin 5; HPLC, high pressure liquid chromatography; LC, liquid chromatography; MS, mass spectrometry; MS/MS, tandem mass spectrometry; RP-HPLC, reverse-phase HPLC; Sap, secreted aspartic protease; TFA, trifluoroacetic acid; YPD, yeast peptone dextrose. 
at $\mathrm{pH}$ ranging from 2 to 7 (Aoki et al., 2011). Thus, Saps are able to degrade a vast number of host's proteins such as salivary lactoferrin, $\alpha_{2}$-macroglobulin, immunoglobulins, the proinflammatory cytokine interleukin-1 $\beta$, cathepsin $\mathrm{D}$, complement components, kininogens and precursors of several blood coagulation factors (Naglik et al., 2003a; Schaller et al., 2005; Bras et al., 2012; Kozik et al., 2015). Recent studies performed in our laboratory showed that Sap-catalyzed fragmentation of some proteins can result in the release of antimicrobial peptides (AMPs) such as hemoglobin-derived hemocidins (Bocheńska et al., 2013), possibly to compete with other microorganisms in the same niche. On the other hand, we found that Saps have an ability to degrade some AMPs, such as LL-37 cathelicidin (Rapala-Kozik et al., 2015) and kininogen-derived NAT26 and HKH20 peptides (Bochenska et al., 2015) and deprive them of antifungal properties. Recently it was shown that C. albicans cells can inactivate His 5 through the hydrolytic action of Saps (Meiller et al., 2009). However, up to date, the data on the proteolytic processing of His 5 by C. albicans enzymes are incomplete, because so far only four out of ten Saps have been studied with respect to this activity (Sap2, Sap5, Sap9-10). The aim of the current study was to investigate the action of all Saps on His5 and to characterize this process in terms of peptide chemistry.

\section{MATERIALS AND METHODS}

Materials. His5 (DSHAKRHHGYKRKFHEKHHSHRGY) peptide was purchased from Eurogentec (Liege, Belgium). Unless otherwise stated, all other chemicals and materials used in this study were obtained from Sigma-Aldrich (St. Louis, MO, USA).

Yeast strain and culturing. The $C$. albicans ATCC 10231 strain from the American Type Culture Collection (Manassas, VA, USA) was cultured overnight at $30^{\circ} \mathrm{C}$ in YPD medium containing $0.5 \%$ yeast extract, $1 \%$ peptone, and $2 \%$ glucose.

Production and purification of Sap1-10 enzymes. Ten Sap isozymes were overproduced in Pichia pastoris expression system (Invitrogen, Carlsbad, CA, USA) and purified according to the published method (Aoki et al., 2011) with slight modifications, described elsewhere (Rapala-Kozik et al., 2015). The high purity of the obtained proteins ( $>95 \%$ for each Sap) was confirmed by sodium dodecyl sulfate-polyacrylamide gel electrophoresis (SDSPAGE) using the Laemmli system (Laemmli, 1970). Protein concentrations were determined by the Bradford assay (Bradford, 1976). The proteolytic activity of all Saps was measured using BODIPY FL casein substrate (Invitrogen) at the optimal $\mathrm{pH}$ for each Sap.

Analysis of the Sap-dependent cleavage of His5. Individual Saps were found to differ markedly in the ability to hydrolyze His5. To make their effects on His5 measurable, we accordingly adjusted the enzyme:substrate ratio (range of 1:50-1:10 000) or/and the incubation time ( 0 h, $0.25 \mathrm{~h}, 0.5 \mathrm{~h}, 1 \mathrm{~h}, 2 \mathrm{~h}$ or $5 \mathrm{~h}$ ). His 5 was used at $50 \mu \mathrm{M}$ concentration in $10 \mathrm{mM}$ acetate buffer at $\mathrm{pH} 4$ (for Sap2, Sap3 and Sap8), pH 5 (optimal for Sap1, Sap4-6 and Sap9) or in $10 \mathrm{mM}$ phosphate buffer at $\mathrm{pH} 6$ (optimal for Sap 7 and Sap10) at $37^{\circ} \mathrm{C}$. After incubation, the reactions were stopped by adding pepstatin A (to a final concentration of $10 \mu \mathrm{M}$ ) and placed on ice for $15 \mathrm{~min}$. The samples were (i) tested for antifungal activity, and (ii) additionally mixed with $0.17 \mathrm{M} \mathrm{HCl}$ and analyzed by reverse-phase high-performance liquid chromatography (RP-HPLC).
RP-HPLC analysis of His 5 cleavage by Sap1-10. Sap-catalyzed cleavage of His 5 was analyzed by HPLC using a Dionex Ultimate 3000 system (Thermo Scientific, Waltham, MA, USA). The peptides were separated on a Eurosil Bioselect 300-5 C-18 column (5 $\mu \mathrm{m}, 4 \mathrm{~mm} \times 250$ $\mathrm{mm}$ ) equipped with a precolumn (both from Knauer, Berlin, Germany) in a two-solvent system (solvent A: $0.1 \%$ TFA in water; solvent B: $0.08 \%$ TFA in $80 \%$ acetonitrile [Merck, Darmstadt, Germany]), at a flow rate of $1 \mathrm{ml} / \mathrm{min}$, with a spectrophotometric detection at 215 $\mathrm{nm}$. The gradient of $0-25 \%$ solvent $\mathrm{B}$ over 31 min was applied for the separations of His 5 fragments. Fractions were collected, evaporated to dryness, and analyzed by mass spectrometry (MS).

Identification of His 5 fragments by mass spectrometry. Evaporated fractions obtained from RPHPLC separations were resuspended in 30\% methanol with $0.1 \% \mathrm{HCOOH}$ and analyzed using an HCTultra ETDII mass spectrometer (Bruker, Bremen, Germany). Samples were directly injected with a syringe pump (KD Scientific, Holliston, MA, USA) at a flow rate of $180 \mu \mathrm{l} / \mathrm{h}$ to an electrospray ionization (ESI) ion source, operated in positive ion mode at a capillary voltage of $3.5 \mathrm{kV}$, nebulizer pressure of 10 psi, drying gas flow of $5 \mathrm{l} / \mathrm{min}$, and ion source temperature of $300^{\circ} \mathrm{C}$. The ion trap analyzer of the spectrometer was set at both MS and MS/MS (tandem mass spectrometry) mode. The peptide identification was performed both manually and automatically, using DataAnalysis ${ }^{\text {TM }} 4.0$ software, Biotools ${ }^{\text {TM }} 3.2$ software (Bruker), and an in-house Mascot server, ver. 2.3.0 (Matrix Science, UK) (Perkins et al., 1999), that searched against the Swiss-Prot database.

Antifungal activity assays - a viability test and a membrane permeabilization assay. C. albicans cultures were harvested, washed three times with 10 $\mathrm{mM}$ phosphate buffer ( $\mathrm{pH}$ 7.4) with $5 \mathrm{mM}$ glucose, counted with use of Burker chamber and diluted to a final density of $2 \times 10^{6}$ colony-forming units (CFU)/ $\mathrm{ml}$. The assays were used for the determination of the candidacidal activities of the AMPs. For viability assay, $5 \times 10^{3}$ yeast cells were incubated for $2 \mathrm{~h}$ at $37^{\circ} \mathrm{C}$ with Sap-cleaved His5 (at a final concentration of 25 $\mu \mathrm{M})$ or peptides collected and evaporated from HPLC analyses in $10 \mathrm{mM}$ phosphate buffer $(\mathrm{pH}$ 7.4) with 5 $\mathrm{mM}$ glucose, which stabilized the yeast growth. After that time, serial dilutions of the incubation mixtures were plated on YPD agar. After a 24-h incubation at $30^{\circ} \mathrm{C}$, the numbers of CFU were counted. The percentage of killed cells was calculated relative to control microorganisms incubated in the absence of AMPs. The measurements were performed in triplicates. Statistical analysis was performed using the Kruskal-Wallis test (included in the GraphPad Prism 6.0 software) at the significance level of $P<0.05$.

Fungal membrane permeabilization was determined using the fluorescent dye SytoxGreen (Molecular Probes, Eugene, OR, USA). The assay mixture contained a greater number of yeast cells $\left(5 \times 10^{4}\right)$ compared with viability assay in order to visualize cell permeation more easily. After $2-\mathrm{h}$ incubation at $37^{\circ} \mathrm{C}, 50 \mu \mathrm{l}$ of mixtures were transferred to 96 -well plate and $0.2 \mu \mathrm{M}$ of SytoxGreen was added. Stained yeast cells were quantified by the observation under a fluorescence microscope Nikon Eclipse Ti (Nikon, Tokyo, Japan) with the filters set at an excitation wavelength of 465-495 $\mathrm{nm}$ and emission at 515-555 nm. The percentage of permeabilized cells was a ratio of the number of green-fluorescent cells to the total number of cells counted. 


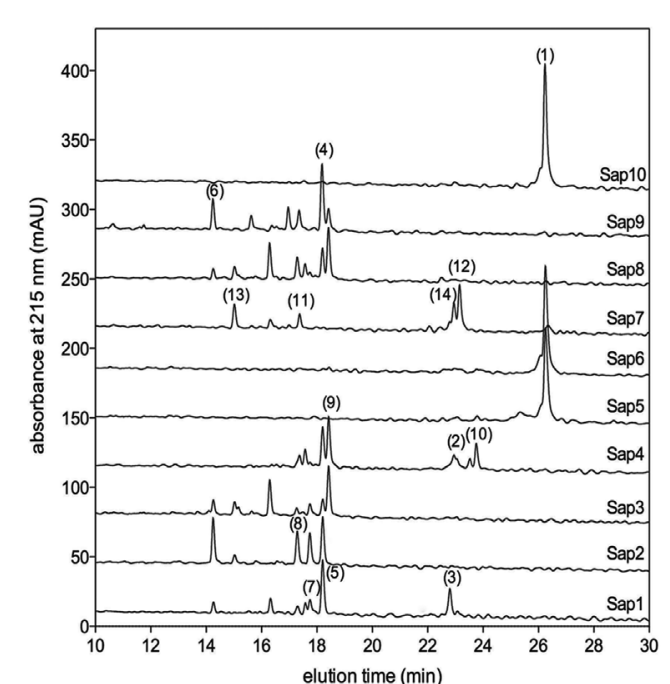

\begin{tabular}{|c|c|c|c|c|}
\hline \multirow[b]{2}{*}{ No. } & \multicolumn{2}{|l|}{ Retention } & \multicolumn{2}{|l|}{ Determined } \\
\hline & time [min] & Sequence & $\begin{array}{l}\text { molecular mass } \\
{[\mathrm{Da}]}\end{array}$ & Produced by Saps \\
\hline 1 & 26.5 & DSHAKRHHGYKRKFHEKHHSHRGY & 3036.3 & - \\
\hline 2 & 23.4 & DSHAKRHHGYKRKFHEK & 2161.4 & Sap1,2,3,4,9 \\
\hline 3 & 23.2 & AKRHHGYKRKFHEK & 1821.0 & Sap1 \\
\hline 4 & 18.6 & HHSHRGY & 891.4 & Sap1,2,3,4,8,9 \\
\hline 5 & 18.2 & AKRHHGY & 867.5 & Sap1 \\
\hline 6 & 14.7 & FHEK & 559.6 & Sap1,2,3,9 \\
\hline 7 & 18 & KRKFHEK & 971.6 & Sap1 \\
\hline 8 & 17.3 & DSHAKRHHGYKRK & 1618.9 & Sap2,3,9 \\
\hline 9 & 18.4 & DSHAKRHHGY & 1206.6 & Sap2,3,4,8 \\
\hline 10 & 23.9 & KRKFHEKHHSHRGY & 1847.1 & Sap4 \\
\hline 11 & 17.7 & DSHAKRHHGYKR & 1490.8 & Sap4,7 \\
\hline 12 & 23.4 & DSHAKRHHGYKRKFHEKHHSH & 2659.9 & Sap7 \\
\hline 13 & 15.3 & RGY & 394.2 & Sap7 \\
\hline 14 & 23 & FHEKHHSHRGY & 1433.7 & Sap $3,7,8$ \\
\hline
\end{tabular}

Figure 1. HPLC profiles of His5 samples treated with Saps. His5 $(50 \mu \mathrm{M})$ was digested with the 10 recombinant Saps at an enzyme:substrate molar ratio of 1:50 in $10 \mathrm{mM}$ buffer at the optimal pH for each enzyme at $37^{\circ} \mathrm{C}$ for $5 \mathrm{~h}$. Representative chromatograms show the ability of seven different Saps to hydrolyze His5. Peptides are annotated with numbers corresponding to the MS/ MS-identified amino acid sequences specified beneath the chromatograms.

\section{RESULTS}

\section{Susceptibility of synthetic His5 peptide to Sap-catalyzed cleavage and inactivation}

Representative chromatograms, obtained from RPHPLC analysis of His5 samples after 5-h digestions with recombinant Saps at the optimal $\mathrm{pH}$ for each individual enzyme and at a 1:50 enzyme:substrate ratio are presented in Fig. 1. This AMP was effectively cleaved by Sap1-4 and Sap7-9. The sequences of all major obtained products were determined by MS/MS and are listed in Fig. 1. Simultaneously conducted viability assay showed that the Sap-dependent degradation of His5 deprived this peptide of antifungal activity (Fig. 2).

\section{The time course of Sap-dependent cleavage of His5 correlates with the decrease in its antifungal activity}

Further experiments were aimed at determining the kinetic characteristics of Sap-dependent His 5 cleavage and of the associated decay in the antifungal activity of this AMP. Additionally, the molar enzyme:substrate ratio was varied according to the previous estimation of the relative cleavage ability of individual Saps. Results are presented in Fig. 3. The cleavage rate decreased in

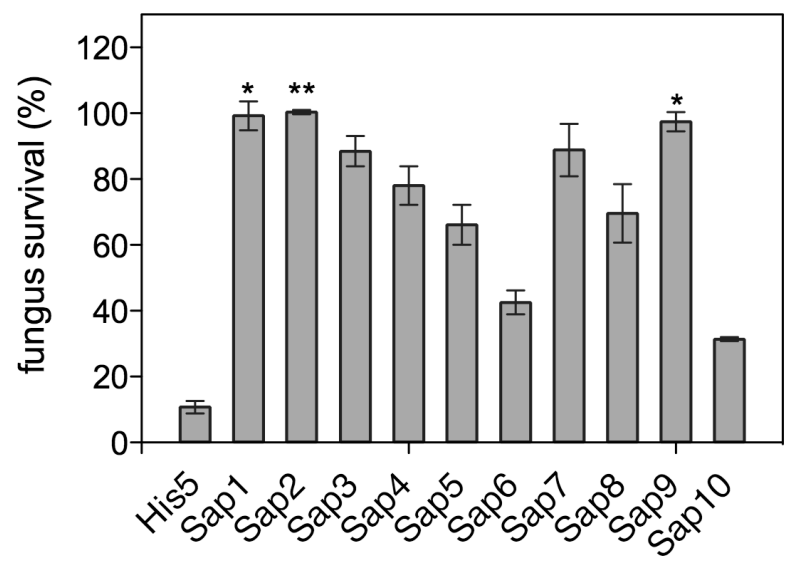

Figure 2. Antifungal activities of Sap-treated His5 samples.

Samples of His5 with Saps, corresponding to those analyzed by HPLC and characterized in Fig. 1, were tested for killing activity against $C$. albicans $\left(5 \times 10^{3} \mathrm{CFU}\right)$. Numbers of viable colonies on agar plates are expressed relative to that of yeast cells not treated with His5. Data bars showing the relationship between the loss of antifungal properties and the Sap-capability to degrade His5, represent mean values from three determinations \pm standard deviation. Asterisks denote the statistical significance at $P<0.01\left({ }^{*}\right)$ or $\left.P<0.05{ }^{*}\right)$.

an order of Sap2 $>$ Sap9 $>$ Sap3 $>$ Sap7 $>$ Sap4 $>$ Sap1 $>$ Sap8. The first cleavage for five out of seven Saps-Sap1-4 (Fig. 3A-D) and Sap9 (Fig. 3G) - was between residues Lys17 and His18 giving DSHAKRHHGYKRKFHEK (2) and HHSHRGY (4) peptides. Simultaneously, DSHAKRHHGYKRK (8) peptide was formed by Sap2-3 and Sap9, and DSHAKRHHGY (9) as well as KRKFHEKHHSHRGY (10) by Sap4. Further fragmentation by Sap1 resulted in AKRHHGYKRKFHEK (3) and AKRHHGY (5) products, by Sap2 and Sap9 in FHEK (6) and additionally by Sap2 in DSHAKRHHGY (9) peptide, whereas further hydrolysis by Sap3 produced DSHAKRHHGY (9) and KRKFHEK (7) peptides. The time course of His 5 degradation by Sap7 (Fig. 3E) was essentially different. The cleavage of His 5 by Sap 7 resulted mainly in the appearance of long DSHAKRHHGYKRKFHEKHHSH (12) peptide which after $1 \mathrm{~h}$ was slowly proceeded to DSHAKRHHGYKR (11) product. The hydrolysis of His5 by Sap8 (Fig. 3F) caused production of DSHAKRHHGY (9), HHSHRGY (4) and FHEKHHSHRGY (14) peptides. Although addition of Saps decreased antifungal activity of His5 itself, with exception of Sap8 (Fig. 4B), the complete loss of antifungal activity appeared after $1 \mathrm{~h}$, suggesting that some peptides can still possess antifungal activities. For Sap9, for instance, the antifungal activity was maintained at a constant level at every measured time.

\section{Fragments of His5 that still possess antifungal activity}

In order to check which His5-derived fragments are responsible for sustained antifungal activity, fractions purified with HPLC method were subjected to two different survival assays. Out of fragments tested, three peptides, His1-21 (12), His1-17 (2) and His1-13 (8) were shown to possess the antifungal activities (Fig. 5). His121 and His1-17 efficiently inactivated fungal cells at the peptide concentration similar to that effective for His5 action, whereas His1-13 was able to decrease fungal survival to about $50 \%$ when incubated with 5000 cells. Increasing the number of cells ten-fold in the fluorescent 

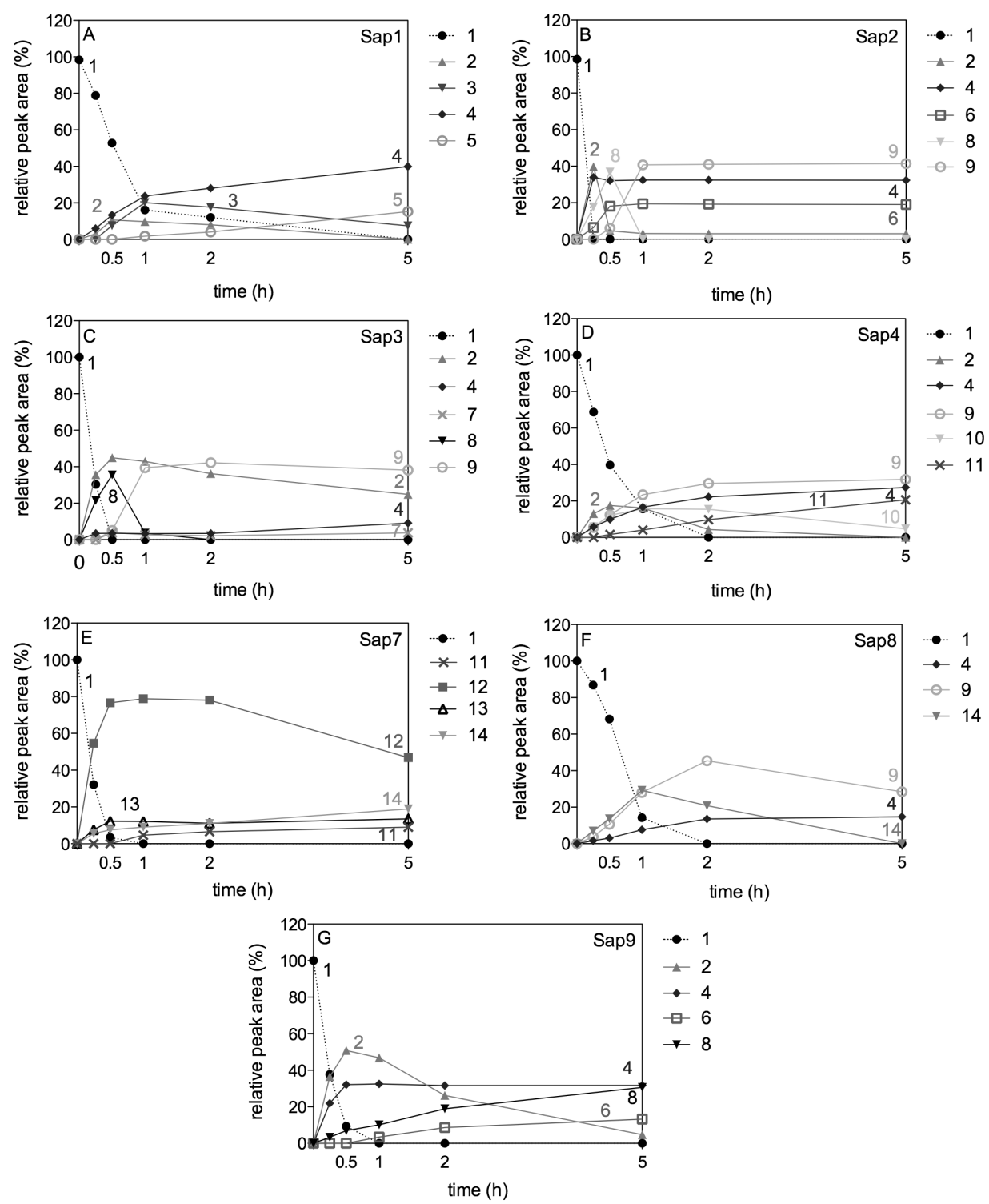

Figure 3. Time course of the cleavage of His 5 by Saps.

His5 $(50 \mu \mathrm{M})$ was incubated with Saps for various times $(0-5 \mathrm{~h})$ at enzyme:substrate ratios different for each Sap: 1:50 for Sap 1 (A), 1:10000 for Sap2 (B), 1:1000 for Sap3 (C), 1:100 for Sap4 (D), 1:100 for Sap7 (E), 1:50 for Sap8 (F) and 1:5000 for Sap9 (G). The peak areas obtained from chromatographic data are expressed relative to that of the substrate at the beginning of the reaction. Only peaks with a relative area of at least 10\% were taken into account and annotated with numbers corresponding to the sequences (determined by MS/MS) specified in Fig. 1.

assay slightly enhanced the survival of $C$. albicans, but the relative antifungal ability of tested peptides remained unchanged.

\section{The $\mathrm{pH}$ dependence of His5 degradation by Saps}

Analysis of the $\mathrm{pH}$ dependence of His5 degradation by Saps (Fig. 6) was performed at $\mathrm{pH} \mathrm{4-7,} \mathrm{at} \mathrm{the} \mathrm{same}$ molar ratio of enzyme:substrate as used in the kinetic studies presented above, for time sufficient for tracking the disappearance of the substrate $(15 \mathrm{~min}$ for Sap2, $30 \mathrm{~min}$ for Sap3 and $1 \mathrm{~h}$ for Sap1, Sap4, Sap7-9). These experiments showed that, despite that Saps display the highest hydrolytic activity at acidic conditions, most proteases tested in this study, with exception of Sap8, were active at $\mathrm{pH}$ between 6-7, i.e., optimal $\mathrm{pH}$ of the saliva. The highest activity at $\mathrm{pH} 7$ was presented by Sap3, Sap4 and Sap9.

\section{DISCUSSION}

C. albicans, being one of the most common pathogen of humans and invading different niches of the organism, including mucosal surface within the oral cavity, exploits several virulence factors to infect the host's tissues and avoid the host's defence mechanisms. One of the most potent and best-studied virulence mechanisms is production of ten different Saps with broad substrate specifity, which can degrade host cell surface molecules and attack cells and molecules of the host immune system to avoid or resist antimicrobial activity (Naglik et al., 2003a; Schaller et al., 2005).

The oral cavity is one of the most heavily microbially colonized parts of our body. The importance of saliva in the maintenance of oral health is well recognized, especially in patients suffering from a reduced salivary output who are much more susceptible to fungal infections than 

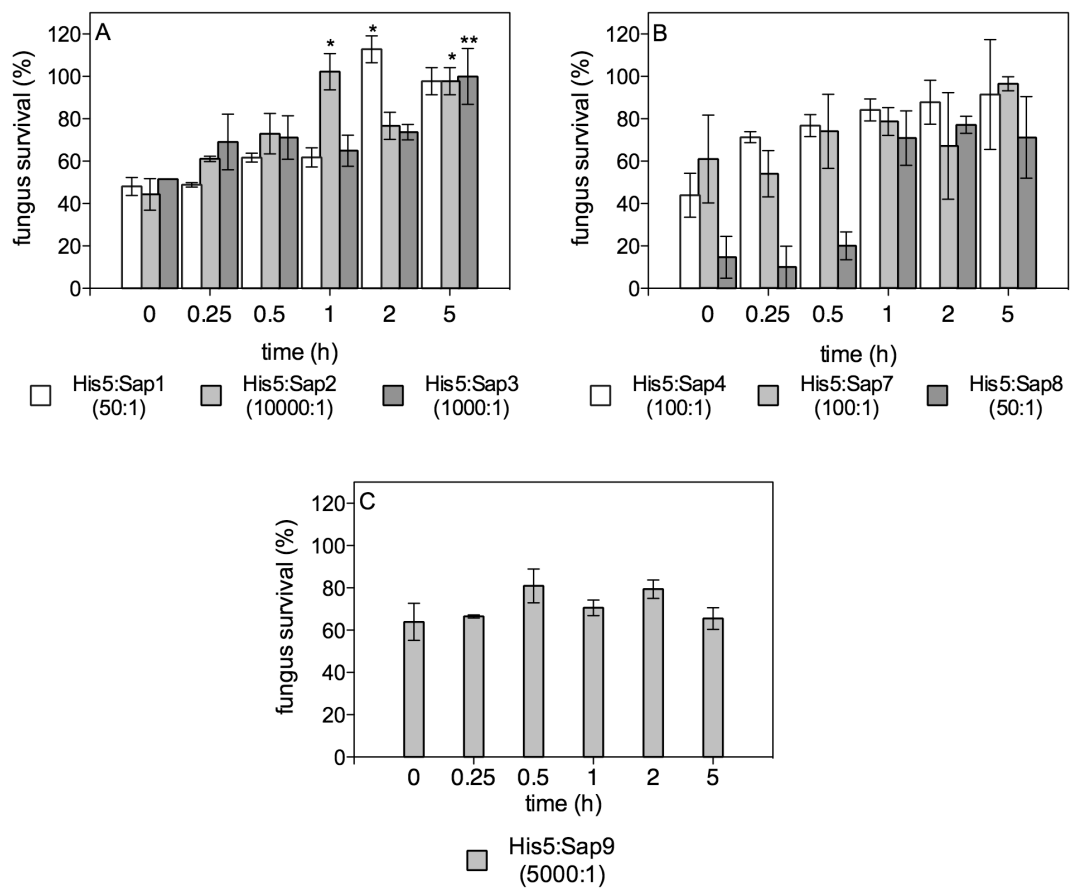

Figure 4. The antifungal activity of Sap-treated His5 samples from kinetic analysis.

His5 $(50 \mu \mathrm{M})$ was incubated with Saps for various times $(0-5 \mathrm{~h})$ at enzyme:substrate ratio different for each Sap as specified in legends. The numbers of viable colonies on agar plates for samples of Sap-treated His5 are expressed relative to that of yeast cells not treated with this AMP. Data bars represent mean values \pm standard deviation (three determinations). Asterisks denote the statistical significance at $P<0.01\left(^{* *}\right)$ or $P<0.05(*)$

healthy individuals (van't Hof et al., 2014). His5 is the potent antimicrobial peptide responsible for protection of oral mucosa. Recently it was shown that $C$. albicans is capable of growing in human saliva (Valentijn-Benz et al., 2015). When the energy metabolism is suppressed, the yeast's resistance against AMPs such as histatins is enhanced (Veerman et al., 2007). Additionally, in the population most vulnerable to oral candidiasis, i.e., HIV patients, an increased growth of C. albicans was correlated with decreased levels of His5 (Torres et al., 2008). In a previous study (Meiller et al., 2009) it was shown that C. albicans cells can degrade His5 in vitro. Based on comparisons between $C$. albicans wild-type strain and Sap-null mutants, the degradation ability was attributed to Sap proteases. Investigation of four proteases, Sap2, Sap5, Sap9 and Sap10, in terms of His 5 fragmentation revealed that Sap5 is ineffective in His 5 cleavage and the main protease responsible for His5 degradation is Sap9. In the present study, we attempted to expand the characteristics of His 5 degradation on all ten $C$. albicans proteases, to investigate this aspect of the dynamic host-pathogen interplay during development of oral candidiasis more deeply. We confirmed that Sap5 was unable to degrade the AMP tested and that the degradation profiles for Sap2 and Sap9 were similar to those previously reported. However, in contrast to that previous work, Sap10 was not able to cleave His5. At present, no reason can be provided to explain this discrepancy.

The key finding presented in this paper is that seven out of ten C. albicans Sap family members (Sap1-4 and Sap7-9, used as purified recombinant proteins) can rapidly degrade salivary AMP, His5. The observed cleavage patterns are consistent with previous reports of Sap specificities (Koelsch et al., 2000; Albrecht et al., 2006; Aoki et al., 2011; Schild et al., 2011). While Sap1-6 and Sap8 have broad substrate specificity and prefer to cleave peptide bonds at positively charged or large hydropho-

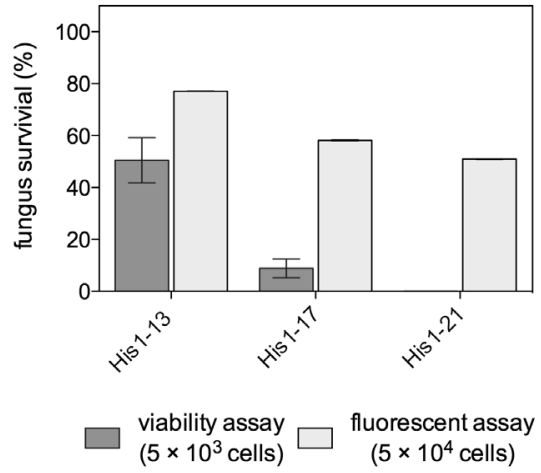

Figure 5. Cleavage fragments derived from His5, still possessing antifungal activity.

The peptides purified with HPLC method were incubated with different amount of $\mathrm{C}$. albicans cells at $37^{\circ} \mathrm{C}$ for $2 \mathrm{~h}$. The percent of C. albicans survival in viability assay represents the number of viable colonies on agar plates expressed relative to yeast cells not treated with this AMP and in fluorescent assay the ratio of dead to living yeast cells stained with SytoxGreen. Data bars represent mean values from three determinations \pm standard deviation.

bic amino acids, such as Arg, Lys, Leu, Phe, and Tyr, Sap7 and Sap9-10 have narrower substrate specificities and prefer amino acids such as Met, Arg and His. These specificity characteristics explain the formation of the same first produc - DSHAKRHHGYKRKFHEK - by five out of seven Saps from synthetic His5, and its derivatives cleaved after Lys or Tyr after longer period of time. They also explain, rarely occurring among proteases, preferred cleavage after histidine residues for Sap7 and after Arg afterwards. The ability of Sap9 to degrade His5 only after Lys is consistent with the confirmed preference of this protease for cleavage of peptide bonds after basic residues. 

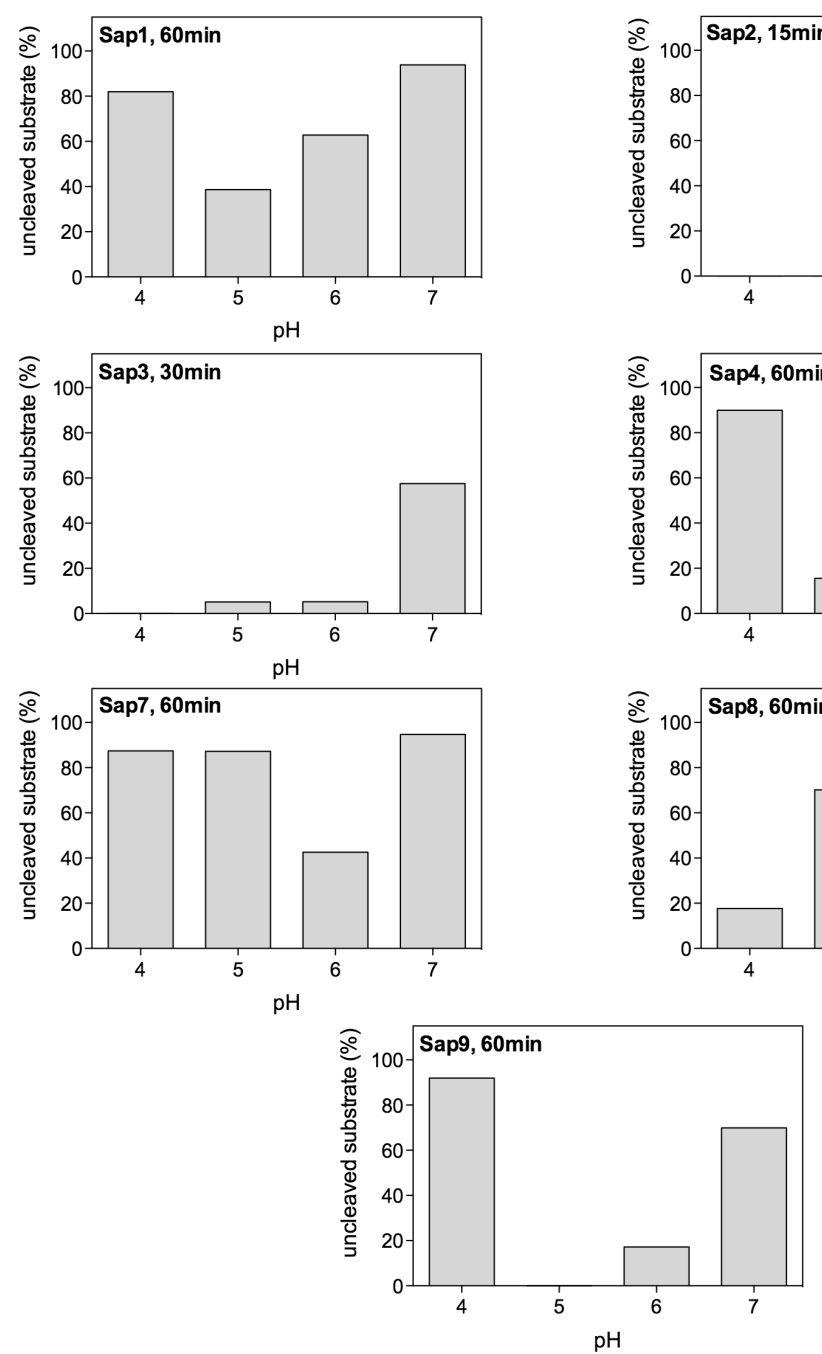

Figure 6. $\mathrm{pH}$-dependence of the degradation of His5 by Saps.

Bars represent the percents of remaining His5 $(5 \mu \mathrm{M})$ separated by RP-HPLC after Sap-treatment at variable enzyme:substrate molar ratio, chosen as sufficient for the activity of each Sap (Fig. 3), at pH within a range between 4 to 7 at $37^{\circ} \mathrm{C}$ for the time specified on graphs.
The hydrolytic cleavage of His5 correlates with the loss of antifungal activity of this peptide. After long time of incubation with Saps, short His5 derivatives appeared and the antimicrobial potency against C. albicans was completely eliminated. However, in the early degradation mixture, antifungal activity was sustained. The reason for al., 1990; Xu et al., 1993; Rothstein et al., 2001; Helmerhorst et al., 2006) there is a large range of His5 derivatives which are able to kill $C$. albicans. These derivatives are the result of His 5 degradation by salivary proteases. One of the peptides which occurs due to salivary degradation is His1-17 whose antifungal action was previously documented (Helmerhorst et al., 2006). Taking into consideration, that His1-21 is the longest of the peptides described and that all, investigated till present, His5-derivatives containing more than 16 amino acid residues maintain their anticandidal activity, there is no surprise that His1-21 is also antimicrobial. Although His1-13, also produced in saliva, was previously not confirmed to be antimicrobial, our studies showed that it can partly decrease fungal survival. However, it can be not sufficient enough to fully kill $C$. albicans, as it is only a part of that is the production of several shorter peptides such as His1-13, His1-17 and His1-21 that still possess some antifungal activity. As reported in previous studies (Raj et

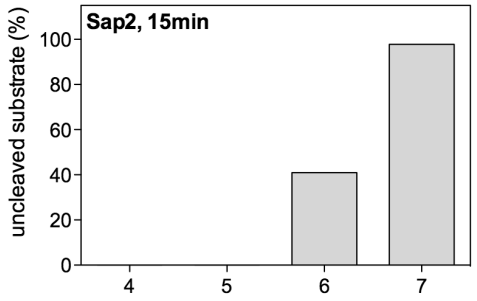

$\mathrm{pH}$

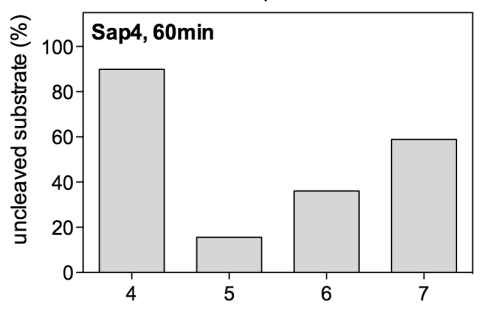

$\mathrm{pH}$

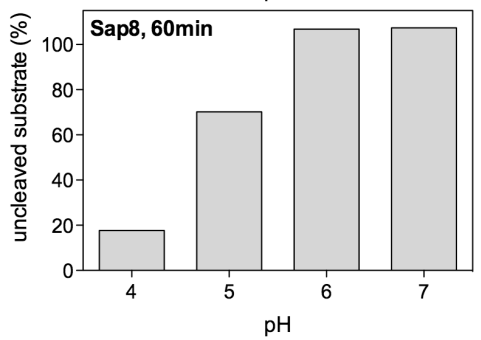

the smallest His5-derivative peptide with conformed antimicrobial properties - AKRHHGYKRKFH. The latter peptide is also the only one from His5 derivatives which currently is in phase I/II and IIb clinical trials and presents the safety, tolerance and efficacy in treatment of oral Candida infections (http://www.demegen.com/articles/P-113-Candidiasis-results.htm).

The analysis of $\mathrm{pH}$ dependence of His5 inactivation by Saps demonstrated that most of the tested proteases, with exception of Sap8, have the ability to degrade AMP in the oral cavity, where normal $\mathrm{pH}$ of saliva is within a range of 6.2-7.6 (Surdacka et al., 2007; Baliga et al., 2013). Regardless of the fact that these enzymes are more active in acidic conditions, the diversity and the broad range of $\mathrm{pH}(2-7)$ optimal for the enzymatic activity, allows these $C$. albicans enzymes to target substrates in different niches of the host organism.

Our current findings corroborate the study of Meiller and coworkers (2009) and also indicate that among the ten members of the Sap family, Sap9 protease is the most effective isoenzyme responsible for His5 degradation. It is the enzyme attached to the cell membrane/ wall through GPI-anchor, crucial for infection process (Albrecht et al., 2006) and most active in the oral environment. $S A P 9$ gene is one of the most highly ex- 
pressed protease genes in vivo during human mucosal infections, in oral reconstituted human epithelium (RHE) models (Naglik et al., 2008). In addition, it is frequently expressed by the yeast both in the commensal stage and during infection (Albrecht et al., 2006). Besides Sap9, also soluble Saps can be relevant, especially Sap3 and Sap4 as they showed His5-degrading ability at $\mathrm{pH}$ 6-7. In vivo analysis of the expression of $C$. albicans SAP1-SAP8 genes in oral candidiasis (Schaller et al., 2001; Naglik et al.,1999; 2003b) indicated the highest frequency of SAP2 expression for both colonized and infected patients. Considering the proteases which were hereby found to degrade His5, SAP1, SAP2, SAP4, SAP7 and SAP8 genes are expressed at a significant level during oral infections (Naglik et al., 2003b). SAP1-3 genes, expressed during mucosal infections (Naglik et al., 1999, 2008) are significant for infection process in general, whereas SAP4 belonging to SAP4-6 subfamily is essential during hyphal invasion (Schaller et al., 2001; Silva et al., 2014). Moreover, the clinical specimen obtained from 29-year old female patient suffering from acute oral candidosis and from a lesion of chronic oral candidosis in an HIVinfected patient showed the presence of SAP1-, 3- and 6 -encoding genes in case of the first patient and $S A P 2$ expression in the latter case (Schaller et al., 1998).

To conclude, in the present study we showed that most of aspartic peptidases, secreted by C. albicans are able to degrade salivary antimicrobial peptide His5; however, during initial fragmentation, His5 derivatives which are still able to reduce the survival of this fungus appear.

\section{Conflicts of interests}

The authors declare that they have no competing interests.

\section{Acknowledgements}

This work was supported in part by the National Science Centre, Poland (grant no. 2013/09/N/NZ1/00201, awarded to O.B.). The Faculty of Biochemistry, Biophysics and Biotechnology of the Jagiellonian University in Krakow is a beneficiary of structural funds from the European Union (grant no. POIG.02.01.00-12-064/08 - "Molecular biotechnology for health") and a partner of the Leading National Research Center (KNOW) supported by the Ministry of Science and Higher Education, Poland.

\section{RFERENCES}

Albrecht A, Felk A, Pichova I, Naglik JR, Schaller M, de Groot P, MacCallum D, Odds FC, Schafer W, Klis F, Monod M, Hube B (2006) Glycosylphosphatidylinositol-anchored proteases of Candida albicans target proteins necessary for both cellular processes and host-pathogen interactions. J Biol Chem 281: 688-694. http://dx.doi. org/10.1074/jbc.M509297200.

Aoki W, Kitahara N, Miura N, Morisaka H, Yamamoto Y, Kuroda K, Ueda M (2011) Comprehensive characterization of secreted aspartic proteases encoded by a virulence gene family in Candida albicans. J Biochem 150: 431-438. http://dx.doi.org/10.1093/jb/mvr073.

Baliga S, Muglikar S, Kale R (2013) Salivary pH: A diagnostic biomarker. J Indian Soc Periodontol 17: 461-465. http://dx.doi. org/10.4103/0972-124X.118317.

Bochenska O, Rapała-Kozik M, Wolak N, Braś G, Kozik A, Dubin A, Aoki W, Ueda M, Mak P (2013) Secreted aspartic peptidases of Candida albicans liberate bactericidal hemocidins from human hemoglobin. Peptides 48: 49-58. http://dx.doi.org/10.1016/j.peptides.2013.07.023

Bochenska O, Rapala-Kozik M, Wolak N, Kamysz W, Grzywacz D, Aoki W, Ueda M, Kozik A (2015) Inactivation of human kininogen-derived antimicrobial peptides by secreted aspartic proteases produced by the pathogenic yeast Candida albicans. Biol Chem 396: 1369-1375. http://dx.doi.org/10.1515/hsz-2015-0167.
Bradford MM (1976) A rapid and sensitive method for the quantitation of microgram quantities of protein utilizing the principle of protein-dye binding. Anal Biochem 72: 248-254.

Bras G, Bochenska O, Rapala-Kozik M, Guevara-Lora I, Faussner A, Kozik A (2012) Extracellular aspartic protease SAP2 of Candida albicans yeast cleaves human kininogens and releases proinflammatory peptides, Met-Lys-bradykinin and des-Arg'-Met-Lys-bradykinin. Biol Chem 393: 829-839. http://dx.doi.org/10.1515/hsz-2012-0157.

Dynowska M, Ejdys E, Biedunkiewicz A, Kubiak D, Sucharzewska E, Rosłan M (2014) Yeasts isolated from frequently in-patients and out-patients. Ann Parasitol 60: 199-206.

Helmerhorst EJ, Alagl AS, Siqueira WL, Oppenheim FG (2006) Oral fluid proteolytic effects on histatin 5 structure and function. Arch Oral Biol 51: 1061-1070. http://dx.doi.org/10.1016/j.archoralbio.2006.06.005.

Hube B, Naglik J (2001) Candida albicans proteinases: resolving the mystery of a gene family. Microbiology 147: 1997-2005.

Koelsch G, Tang J, Loy JA, Monod M, Jackson K, Foundling SI, Lin $\mathrm{X}$ (2000) Enzymic characteristics of secreted aspartic proteases of Candida albicans. Biochim Biophys Acta 1480: 117-131.

Kozik A, Gogol M, Bochenska O, Karkowska-Kuleta J, Wolak N, Kamysz W, Aoki W, Ueda M, Faussner A, Rapala-Kozik M (2015) Kinin release from human kininogen by 10 aspartic proteases produced by pathogenic yeast Candida albicans. BMC Microbiol 15: 1-14. http://dx.doi/10.1186/s12866-015-0394-8.

Laemmli UK (1970) Cleavage of structural proteins during the assembly of the head of bacteriophage T4. Nature 227: 680-685.

Meiller TF, Hube B, Schild L, Shirtliff ME, Scheper M, Winkler R, Ton A, Jabra-Rizk MA (2009) A novel immune evasion strategy of Candida albicans: proteolytic cleavage of a salivary antimicrobial peptide. PloS One 4: e5039. http://dx.doi.org/10.1371/journal. pone.0005039.

Moffa EB, Mussi MCM, Xiao Y, Garrido SS, Machado MAAM, Giampaolo ET, Siqueira WL (2015) Histatin 5 inhibits adhesion of C. albicans to reconstructed human oral epithelium. Front Microbiol 6: 1-7. http://dx.doi.org/10.3389/ fmicb.2015.00885.

Naglik JR, Newport G, White TC, Fernandes-Naglik LL, Greenspan JS, Greenspan D, Sweet SP, Challacombe SJ, Agabian N (1999) In vivo analysis of secreted aspartyl proteinase expression in human oral candidiasis. Infect Immun 67: 2482-2490.

Naglik JR, Challacombe SJ, Hube B (2003a) Candida albicans secreted aspartyl proteinases in virulence and pathogenesis. Microbiol Mol Biol Rev 67: 400-428.

Naglik JR, Rodgers C, Shirlaw PJ, Dobbie JL, Fernandes-Naglik LL, Greenspan D, Agabian N, Challacombe SJ (2003b) Differential expression of Candida albicans secreted aspartyl proteinase and phospholipase B genes in humans correlates with active oral and vaginal infections. J Infect Dis 188: 469-479. http://dx.doi. org/10.1086/376536.

Naglik J, Albrecht A, Bader O, Hube B (2004) Candida albicans proteinases and host/pathogen interactions. Cell Microbiol 6: 915-926.

Naglik JR, Moyes D, Makwana J, Kanzaria P, Tsichlaki E, Weindl G, Tappuni AR, Rodgers CA, Woodman AJ, Challacombe SJ, Schaller M, Hube B (2008) Quantitative expression of the Candida albicans secreted aspartyl proteinase gene family in human oral and vaginal candidiasis. Microbiology 154: 3266-3280. http://dx.doi.org/10.1099/ mic.0.2008/022293-0.

Perkins D, Pappin D, Creasy D, Cottrell J (1999) Probability-based protein identification by searching sequence databases using mass spectrometry data. Electrophoresis 20: 3551-3567.

Puri S, Edgerton M (2014) How does it kill?: Understanding the candidacidal mechanism of salivary histatin 5. Eukaryotic Cell 13: 958-964. http://dx.doi.org/10.1128/EC.00095-14.

Raj PA, Edgerton M, Levine MJ (1990) Salivary histatin 5: Dependence of sequence, chain length, and helical conformation for candidacidal activity. I Biol Chem 265: 3898-3905.

Rapala-Kozik M, Bochenska O, Zawrotniak M, Wolak N, Trebacz G, Gogol M, Ostrowska D, Aoki W, Ueda M, Kozik, A (2015) Inactivation of the antifungal and immunomodulatory properties of human cathelicidin LL-37 by aspartic proteases produced by the pathogenic yeast Candida albicans. Inf Immun 83: 2518-2530. http:// dx.doi.org/10.1128/IAI.00023-15.

Rothstein DM, Spacciapoli P, Tran LT, Xu T, Roberts FD, Dalla Serra M, Buxton DK, Oppenheim FG, Friden P (2001) Anticandida activity is retained in P-113, a 12-amino-acid fragment of histatin 5. Antimicrob Agents and Chemother 45: 1367-1373. http://dx.doi. org/10.1128/AAC.45.5.1367.

Samaranayake LP, Keung Leung W, Jin, L (2009) Oral mucosal fungal infections. Periodontology 2000 49: 39-59. http://dx.doi.org/10.1111/ j.1600-0757.2008.00291.x.

Schaller M, Korting HC, Schafer W, Sanglard D, Hube B (1998) Investigations on the regulation of secreted aspartyl proteases in a model of oral candidiasis in vivo. Mycoses 41 Suppl 2: 69-73.

Schaller M, Januschke E, Schackert C, Woerle B, Korting HC (2001) Different isoforms of secreted aspartyl proteinases (Sap) are ex- 
pressed by Candida albicans during oral and cutaneous candidosis in vivo. J Med Microbiol 50: 743-747.

Schaller M, Borelli C, Korting HC, Hube B (2005) Hydrolytic enzymes as virulence factors of Candida albicans. Mycoses 48: 365-377.

Schild L, Heyken A, de Groot PWJ, Hiller E, Mock M, de Koster C,. Horn U, Rupp S, Hube B (2011) Proteolytic cleavage of covalently linked cell wall proteins by Candida albicans Sap9 and Sap10. Eukaryot Cell 10: 98-109.

Silva NC, Nery JM, Dias ALT (2014) Aspartic proteinases of Candida spp.: role in pathogenicity and antifungal resistance. Mycoses 57: 1-11. http://dx.doi.org/10.1111/myc.12095.

Singh A, Verma R, Murari A, Agrawal A (2014) Oral candidiasis: an overview. J Oral Maxillofacial Pathol 18: 81-85. http://dx.doi. org/10.4103/0973?029X.141325.

Surdacka A, Strzyka K, Rydzewska A (2007) Changeability of oral cavity environment. Eur J Dentistry 1: 14-17.

Swidergall M, Ernst JF (2014) Interplay between Candida albicans and the antimicrobial peptide armory. Eukaryot Cell 13: 950-957. http:// dx.doi.org/10.1128/EC.00093-14.
Torres SR, Garzino-Demo A, Meeks V, Meiller TF, Jabra-Rizk MA (2008) Salivary Histatin-5 and oral fungal colonization in HIV + individuals. Mycoses 52: 11-15.

Valentijn-Benz M, Nazmi K, Brand H S, van't Hof W, Veerman ECI

(2015) Growth of Candida albicans in human saliva is supported by low-molecular-mass compounds. FEMS Yeast Research 15: 1-8. http://dx.doi.org/10.1093/femsyr/fov088.

van't Hof W, Veerman ECI, Nieuw Amerongen AV, Ligtenberg AJM (2014) Antimicrobial defense systems in saliva. Monogr Oral Sci 24: 40-51. http://dx.doi.org/10.1159/000358783.

Veerman ECI, Valentijn-Benz M, Nazmi K, Ruissen ALA, WalgreenWeterings E, van Marle J, Doust AB, van 't Hof W, Bolscher JR, Amerongen AVN (2007) Energy depletion protects Candida albicans against antimicrobial peptides by rigidifying its cell membrane. J Biol Chem 282: 18831-18841. http://dx.doi.org/10.1074/jbc. M610555200.

Xu L, Lal K, Santarpia R P 3rd, Pollock JJ (1993) Salivary proteolysis of histidine-rich polypeptides and the antifungal activity of peptide degradation products. Arch Oral Biol 38: 277-283. 